\title{
POTENTIAL OF INTER- AND INTRA-SPECIES VARIABILITY OF CHD1 GENE IN BIRDS AS A FORENSIC TOOL
}

\author{
Dajana DAVITKOV ${ }^{*}$, Milos VUCICEVIC ${ }^{2}$, Uros GLAVINIC ${ }^{3}$, Ivan SKADRIC ${ }^{4}$, \\ Vladimir NESIC 1 , Jevrosima STEVANOVIC ${ }^{3}$, Zoran STANIMIROVIC ${ }^{3}$
}

${ }^{1}$ Department of Forensic Veterinary Medicine, Faculty of Veterinary Medicine, University of Belgrade, Bul. oslobodjenja 18, 11000 Belgrade, Serbia; ${ }^{2}$ Department of Equine, Small Animal, Poultry and Wild Animal Diseases, Faculty of Veterinary Medicine, University of Belgrade, Bul. oslobodjenja 18, 11000 Belgrade, Serbia; ${ }^{3}$ Department of Biology, Faculty of Veterinary Medicine, University of Belgrade, Bul. oslobodjenja 18, 11000 Belgrade, Serbia; ${ }^{4}$ Faculty of Medicine, University of Belgrade, dr Subotića 8, Belgrade, Serbia

(Received 01 April, Accepted 14 June 2021)

\begin{abstract}
Nowadays, illegal trafficking and smuggling of animals are among the greatest threats to many avian species. Most commonly smuggled birds belong to parrots, song birds, raptor species and owls. All of these species are protected by national and international legislations. In order to prevent and reduce wildlife trafficking, DNA methods have become an important forensic tool in species and sex identification. In this study, CHD1R/CHD1F primer pair was used to amplify a part of the CHD1 gene from 65 birds that belong to 43 species. For 36 species this is the first time that the length of CHD1 amplicons was measured for the purpose of species determination. The results were visualized using capillary electrophoresis and enabled simultaneous determination of sex and species. Based on the number of amplicons (two in females, one in males) sex was successfully determined in all species, even in cases where gel electrophoresis failed to give results. Moreover, the species was successfully determined in most bird species based on the species-specific sizes of CHD1 amplicon. The method used in this study is of great importance for veterinary forensic medicine and the prevention of wildlife smuggling. Still, further work is necessary to confirm the effectiveness of the method in all bird species.
\end{abstract}

Key words: birds, capillary electrophoresis, CHD1 gene, species determination, sex determination, wildlife trafficking

\section{INTRODUCTION}

Wildlife trafficking, including illegal poaching, trade, and transport of wildlife are considered global problems, spreading from low-income to wealthy countries [1-3]. It is estimated that the annual profit from this illicit activity reaches 2.3 million euros

*Corresponding author: e-mail: dajana@vet.bg.ac.rs 
only in the EU, and up to 23 billion in the USA $[3,4]$. The main subjects of trade, seized within the EU are live birds, followed by live plants, bird and mammal bodies, parts and derivatives. Even though small songbirds, raptor species, parrots, and owls are protected by CITES (https://www.cites.org), the Bonn convention (https://www. cms.int/) as well as by national legislation [5], they are still subject of reported seizures in $79 \%$ of all cases in the EU [3]. This activity puts at risk thousands of species and encompasses a risk of zoonotic diseases host by wild animals [3].

Members of the ordo Psittaciformes are usually caught because of their vocal abilities, the beauty of the feathers and use as companion animals [6]. However, members of other bird families are also at risk of illegal trafficking. The consequence is that today almost all Psittaciformes species are listed in CITES Appendix I (only three of them are listed in Appendix II). The most commonly smuggled Psittaciformes species are Amazona aestiva, A. ochrocephala, Ara chloroptera, A. ararauna, Pionites melanocephala and Aratinga solstitialis. In 2018349 live birds were seized in the EU, and 316 of them were parrots such as Agapornis fischeri, A. personatus (App. II/Annex B) and Psittacus erithacus [3].

To reduce wildlife trafficking and illegal hunting, international organizations and national agencies highly depend on forensic investigations which include species and sex identification of animals [7-9]. In the last decades, molecular techniques have become very valuable forensic tools that enable, among other things, identification of species from a very low quantity of samples $[2,10,11]$ of various types (e.g. tissues, scales, hairs, feathers, eggshells). In forensics, identification of avian species is necessary to determine the origin of fragments of feathers that can be found in smugglers' bags.

The central role in modern forensic approaches is reserved for DNA analysis as an unavoidable step in law enforcement and endangered bird species protection [10]. Different molecular techniques are used for sex and species determination, such as DNA barcoding [12,13], polymerase chain reaction-restriction fragment length polymorphism (PCR-RFLP) [14], metabarcoding avian environmental DNA [15], and DNA sequencing $[16,17]$. There are plenty of papers related to mammalian species identification $[11,18,19]$, while only few related to bird species identification are available [10].

Along with the application in forensics, species identification and sex determination are very important in the taxonomic classification and genetic diversity studies, conservation programs as well as in bird breeding and farming [20,21]. When it comes to birds' sex determination, there are a lot of different molecular techniques applicable for that task $[10,22,23]$. The most successful genetic marker for sex determination in avian species is Chromodomain Helicase DNA Binding Protein 1 (CHD1) gene due to both high degree of conservation even among distant species and insertion-deletion polymorphism difference between CHD1 genes on Z and W chromosomes [7]. Two primer sets are commonly used for sex determination, 2550F/2718R and P2/ P8, but to the best of our knowledge, only two studies tackled the extension of 
CHD1F/CHD1R primer set in species identification through precise fragment length determination $[10,24]$.

Regarding the lack of information on the molecular technique that can be used for both sex and species determination in birds, but also the absence of studies that examined the variability of amplicon lengths across endangered bird species, we tested the performance of $\mathrm{CHD} 1 \mathrm{~F} / \mathrm{CHD} 1 \mathrm{R}$ primers by capillary electrophoresis. We aimed to provide more information on partial CHD1 variability from 43 species that are often the subject of wildlife trafficking and assess capillary electrophoresis as a method of choice for sex and species determination in birds and the potential of this methodology as a forensics tool in wildlife trafficking.

\section{MATERIAL AND METHODS}

\section{Sampling and DNA extraction}

A total of 65 samples were collected from 43 bird species protected under the Law of the Republic of Serbia or EU regulations. Ethics committee approval was obtained by the Ministry of Agriculture, Forestry and Water Management (number 323-070036412017-0515).

Samples were provided by either Zoological Garden of Belgrade or were taken during post-mortem examination at the Department of Veterinary Forensic medicine, Faculty of Veterinary medicine, University of Belgrade. From each bird, samples were taken by plucking at least three to five thoracic feathers and stored in a separate zip bag. After sampling, all live birds were released unharmed. DNA was extracted from the feathers. Quills were cut into 2- to 5-mm-long pieces in sealed $1.5 \mathrm{ml}$ tubes. Afterwards, DNA was extracted using the DNeasy® Blood \& Tissue Kit, Cat. No 69504 (Qiagen, Valencia, CA) following a manufacturer protocol.

\section{PCR Amplification}

A pair of dye-labelled primers were used to amplify parts of the CHD1 gene: CHD1F (FAM-5'-TATCGTCAGT'TTCCTT'TTCAGGT-3') and CHD1R (5'-CCT'TTTATTGATCCATCAAGCCT-3') designed by Lee et al. (2010). DNA amplification was carried out in $25 \mu \mathrm{L}$ reaction volume mixing $12.5 \mu \mathrm{L}$ of KAPA2G Robust HotStart ReadyMix (Kapa Biosystems) and $1.25 \mu \mathrm{L}$ of each primer (conc. $10 \mu \mathrm{M}$ ) and $10 \mu \mathrm{L}$ of extracted DNA (approx. $200 \mathrm{ng} / \mu \mathrm{L}$ ). The thermal protocol was modified according to Bosnjak et al. [8] and involved 3 min of initial denaturation at $95^{\circ} \mathrm{C}$, followed by 35 cycles of denaturation $\left(95^{\circ} \mathrm{C}, 15 \mathrm{sec}\right)$, primer annealing on $52^{\circ} \mathrm{C}$ for $30 \mathrm{sec}$, extension $\left(72^{\circ} \mathrm{C}, 15 \mathrm{sec}\right)$, and a final extension step at $72^{\circ} \mathrm{C}$, which lasted $8 \mathrm{~min}$. For sex determination on agarose gel, the same thermal protocol was used, with 2550F (5'-GTTACTGATTCGTCTACGAGA-3') and 2718R (5'-ATTGAAATGATCCAGTGCTTG-3') set of primers. 


\section{Agarose gel electrophoresis}

Total of $10 \mu \mathrm{L}$ of PCR product was used for electrophoresis. After the separation in $2 \%$ agarose gel and staining in ethidium bromide, PCR products were visualized with UV light. A commercial O'RangeRulerTM 50bp DNA Ladder (Thermo Scientific, Massachusetts, United States) was used as the size marker to determine whether Zand W-bands were obtained.

\section{Capillary electrophoresis}

After checking the dye-labelled PCR amplicons on the agarose gel, from the remaining PCR product, $1 \mu \mathrm{L}$ was used for capillary electrophoresis fragment separation. Capillary electrophoresis was performed using polymer type POP-6, $50 \mathrm{~cm}$ long capillaries, and internal size standard LIZ500 (Applied Biosystems, Foster City, USA) on ABI3130 DNA analyzer (Applied Biosystems, Foster City, USA) according to the protocol described by Lee et al. (2010). For data analyzing authors used GeneMapper 3.1 (Applied Biosystems).

\section{RESULTS}

The amplification products have been obtained for all analyzed samples by both agarose gel electrophoresis and capillary electrophoresis (Table 1). On capillary electrophoresis, one amplification product was observed in 26 collected samples indicating male gender, while two amplification products were detected in 39 samples indicating the female gender. In all cases, the size of CHD amplicons of Z chromosomes (CHD-Z amplicon) was larger compared to amplicons of W chromosome (CHD-W amplicon). In the case of 41 bird species (out of 43 analyzed in this study), the length of CHD-Z amplicons was identical in all samples originating from the same species. In remained two species involved in this study, Buteo buteo and Cygnus cygnus, CHD-Z amplicons from two samples of the same species differed slightly, $3 \mathrm{bp}$ in the case of the former, and $1 \mathrm{bp}$ in the case of the latter (Samples No. 24 and 25, 10 and 11 in Table 1). In case of 42 species, the length of CHD-W amplicons was identical in samples originating from the same species; the only exception was observed in Tyto alba where samples of two females generated CHD-W amplicon that differed in four base pairs (Samples No. 17 and 18 in Table 1). The smallest difference in fragment length (42 and 59 bp) between CHD-Z and CHD-W fragments of the same species was noticed in samples of birds belonging to Strigiformes (Table 1). The same size of CHD-Z amplicon was detected in some samples originating from different species, but mostly in cases of those that belong to the same order or even family. However, in those samples (from different species but with the same length of CHD-Z sequence) CHD-W amplicons were of different sizes (Samples No. 11/12 and 56; 29 and 36; 23 and 39/40).

In 4 out of 65 birds we found disagreement in sex determination results between two methods. All four birds where disagreements were present originated from ordo 
Strigiformes. In other bird species, such as birds from ordo Psittaciformes, gender has been successfully determined using gel electrophoresis (Figure 1).

Table 1. Lengths of CHD-Z and CHD-W amplicons obtained with CHD1F/CHD1R primers and determined by capillary electrophoresis, along with the sex determined by both gel and capillary electrophoresis

\begin{tabular}{|c|c|c|c|c|c|c|}
\hline $\mathrm{N}^{\circ}$ & Species & Ordo & $\begin{array}{l}N^{\prime} \\
\frac{1}{0} \\
\frac{1}{2}\end{array}$ & $\begin{array}{l}\underbrace{\prime} \\
\frac{1}{2} \\
\frac{1}{2}\end{array}$ & $\begin{array}{c}\text { Sex affirmed } \\
\text { by capillary } \\
\text { electrophoresis }\end{array}$ & $\begin{array}{c}\text { Sex affirmed } \\
\text { by agarose } \\
\text { gel }\end{array}$ \\
\hline 1 & Gallus gallus domesticus & \multirow{6}{*}{ Galliformes } & 466 & & $\mathrm{M}$ & $\mathrm{M}$ \\
\hline 2 & Gallus gallus domesticus & & 466 & 322 & $\mathrm{~F}$ & $\mathrm{~F}$ \\
\hline 3 & Pavo cristatus & & 460 & 316 & $\mathrm{~F}$ & $\mathrm{~F}$ \\
\hline 4 & Pavo cristatus & & 460 & & M & M \\
\hline 5 & Phasianus colchicus & & 465 & 319 & $\mathrm{~F}$ & $\mathrm{~F}$ \\
\hline 6 & Phasianus colchicus & & 465 & & M & M \\
\hline 7 & Anas platyrbynchos & \multirow{8}{*}{ Anseriformes } & 443 & & M & M \\
\hline 8 & Anas platyrbynchos & & 443 & 327 & $\mathrm{~F}$ & $\mathrm{~F}$ \\
\hline 9 & Ciconia ciconia* & & 540 & 336 & $\mathrm{~F}$ & $\mathrm{~F}$ \\
\hline 10 & Cygnus cygnus* & & 455 & & M & M \\
\hline 11 & Cygnus cygnus* & & 454 & 351 & $\mathrm{~F}$ & $\mathrm{~F}$ \\
\hline 12 & Tadorna ferruginea* & & 445 & & M & M \\
\hline 13 & Tadorna ferruginea* & & 445 & 340 & $\mathrm{~F}$ & $\mathrm{~F}$ \\
\hline 14 & Phoenicopterus roseus* & & 540 & & M & M \\
\hline 15 & Columba livia & \multirow{2}{*}{ Columbiformes } & 524 & & $\mathrm{M}$ & M \\
\hline 16 & Columba livia & & 524 & 328 & $\mathrm{~F}$ & $\mathrm{~F}$ \\
\hline 17 & Tyto alba* & \multirow{7}{*}{ Strigiformes } & 513 & 471 & $\mathrm{~F}$ & M \\
\hline 18 & Tyto alba* & & 513 & 475 & $\mathrm{~F}$ & M \\
\hline 19 & Athene noctua* & & 529 & & M & M \\
\hline 20 & Athene noctua* & & 529 & 427 & $\mathrm{~F}$ & M \\
\hline 21 & Bubo bubo* & & 521 & & M & M \\
\hline 22 & Glaucidum passerinum* & & 530 & 471 & $\mathrm{~F}$ & M \\
\hline 23 & Strix aluco* & & 329 & & M & M \\
\hline 24 & Buteo buteo* & \multirow{12}{*}{ Accipitriformes } & 566 & & M & M \\
\hline 25 & Buteo buteo* & & 563 & 329 & $\mathrm{~F}$ & $\mathrm{~F}$ \\
\hline 26 & Accipiter nisus* & & 545 & 329 & $\mathrm{~F}$ & $\mathrm{~F}$ \\
\hline 27 & Falco tinnunculus & & 526 & & M & M \\
\hline 28 & Falco tinnunculus & & 526 & 339 & $\mathrm{~F}$ & $\mathrm{~F}$ \\
\hline 29 & Aquila beliaca* & & 525 & 246 & $\mathrm{~F}$ & $\mathrm{~F}$ \\
\hline 30 & Neophron percnopterus* & & 556 & 328 & $\mathrm{~F}$ & $\mathrm{~F}$ \\
\hline 31 & Neophron percnopterus* & & 556 & & M & M \\
\hline 32 & Gyps fulvus* & & 536 & & M & M \\
\hline 33 & Haliaeetus albicila* & & 600 & 329 & $\mathrm{~F}$ & $\mathrm{~F}$ \\
\hline 34 & Haliaeetus albicila* & & 600 & 329 & $\mathrm{~F}$ & $\mathrm{~F}$ \\
\hline 35 & Accipiter gentilis* & & 514 & & $\mathrm{M}$ & M \\
\hline
\end{tabular}


cont. Table 1

\begin{tabular}{|c|c|c|c|c|c|c|}
\hline 36 & Ara ararauna* & \multirow{30}{*}{ Psittaciformes } & 518 & 329 & $\mathrm{~F}$ & $\mathrm{~F}$ \\
\hline 37 & Ara ararauna* & & 518 & & M & M \\
\hline 38 & Ara chloroptera* & & 521 & 332 & $\mathrm{~F}$ & $\mathrm{~F}$ \\
\hline 39 & Ara macao* & & 521 & 371 & $\mathrm{~F}$ & $\mathrm{~F}$ \\
\hline 40 & Ara nobilis* & & 519 & & M & M \\
\hline 41 & Ara moluccensis* & & 515 & & M & M \\
\hline 42 & Cacatua sulphurea* & & 514 & 457 & $\mathrm{~F}$ & $\mathrm{~F}$ \\
\hline 43 & Cacatua alba* & & 514 & 308 & $\mathrm{~F}$ & $\mathrm{~F}$ \\
\hline 44 & Amazona barbadensis* & & 427 & & M & M \\
\hline 45 & Amazona venezuela* & & 525 & & M & M \\
\hline 46 & Amazona venezuela* & & 525 & 329 & $\mathrm{~F}$ & $\mathrm{~F}$ \\
\hline 47 & Amazona nestova* & & 522 & 358 & $\mathrm{~F}$ & $\mathrm{~F}$ \\
\hline 48 & Amarona aestiva* & & 520 & & M & M \\
\hline 49 & Amazona aestiva* & & 520 & 329 & $\mathrm{~F}$ & $\mathrm{~F}$ \\
\hline 50 & Amazona finschi* & & 526 & 330 & $\mathrm{~F}$ & $\mathrm{~F}$ \\
\hline 51 & Amazona finschi* & & 526 & 330 & $\mathrm{~F}$ & $\mathrm{~F}$ \\
\hline 52 & Amazona ochrocephala & & 520 & 395 & $\mathrm{~F}$ & $\mathrm{~F}$ \\
\hline 53 & Amazon ochrocephala & & 520 & 395 & $\mathrm{~F}$ & $\mathrm{~F}$ \\
\hline 54 & Amazona albiguens* & & 526 & 324 & $\mathrm{~F}$ & $\mathrm{~F}$ \\
\hline 55 & Pyrrbura molinae* & & 523 & 330 & $\mathrm{~F}$ & $\mathrm{~F}$ \\
\hline 56 & Pyrrbura molinae ${ }^{*}$ & & 523 & & M & M \\
\hline 57 & Pyrrbura conura* & & 524 & & M & M \\
\hline 58 & Pyrrbura conura* & & 524 & 329 & $\mathrm{~F}$ & $\mathrm{~F}$ \\
\hline 59 & Pionites melanocephala* & & 518 & & M & M \\
\hline 60 & Pionites melanocephala* & & 518 & 328 & $\mathrm{~F}$ & $\mathrm{~F}$ \\
\hline 61 & Amazona leucocephala* & & 525 & 358 & $\mathrm{~F}$ & $\mathrm{~F}$ \\
\hline 62 & Polytelis swansonii* & & 513 & 473 & $\mathrm{~F}$ & $\mathrm{~F}$ \\
\hline 63 & Pssitacus erithacus* & & 512 & 329 & $\mathrm{~F}$ & $\mathrm{~F}$ \\
\hline 64 & Pssitacus erithacus* & & 512 & & M & M \\
\hline 65 & Amazona albifrons* & & 526 & 329 & $\mathrm{~F}$ & $\mathrm{~F}$ \\
\hline
\end{tabular}

${ }^{*}$ )According to our knowledge in this study the length of CHD-Z and CHD-W amplicons for these species were determined for the first time.

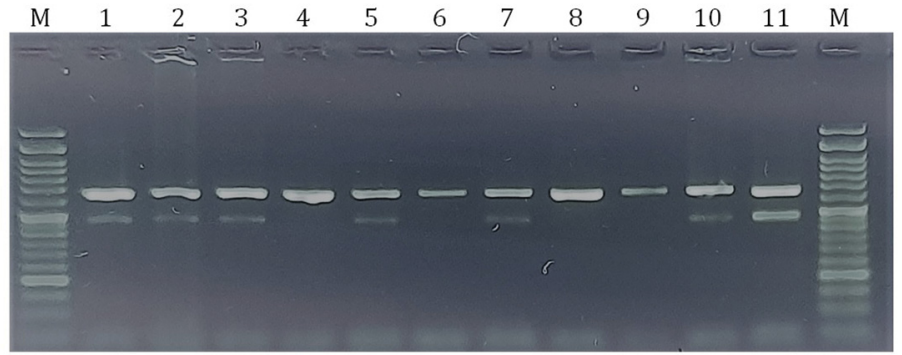

Figure 1. Sex determination in different avian species on agarose gel with $2550 \mathrm{~F} / 2718 \mathrm{R}$ set of primers M - Ladder, 1 - Ara chloroptera (), 2 - Ara ararauna ()); 3 - Amazona aestiva ()); 4 - Amazona aestiva (ठ); 5 - Pyrrbura molinae (+); 6 - Pyrrbura molinae (ठ); 7 - Amazona venezuela

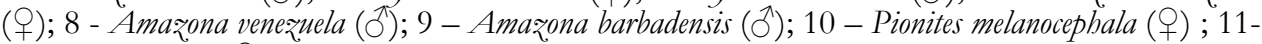
Pssitacus erithacus (+) 


\section{DISCUSSION}

This study involved bird species that are protected by national or international regulations and are most often the subject of illegal trade on the international or national level (5, https://www.cites.org). CHD1F/CHD1R primer set was used because it produces smaller fragments more appropriate for capillary electrophoresis [10]. Moreover, this primer set is better for less abundant and degraded DNA samples compared to $2550 \mathrm{~F} / 2718 \mathrm{R}$ primer set, also commonly used for sex determination. According to the results of Lee et al. (2010), the size of CHD-Z and CHD-W amplicon can be very similar in species of the same order or family. The same applies to our results (Table 1). For 36 species in this study the lenght of CHD-Z and CHD-W amplicon was analised for the first time.

The results were consistent in terms of the equality in size of CHD-Z amplicon within samples originating from the same bird species, excepting Buteo buteo and Cygnus cygnus. This could be explained with genetic variability which can be up to three base pairs within the samples from the same species, based on Lee et al. (2010). In our study, twelve samples were from bird species analyzed previously by Lee et al. (2010). Ten of them (Nos. 1-8, 15 and 16 in Table 1), produced amplicons of the same length (both CHD-Z and CHD-W) as previoulsy reported (Lee et al., 2010). This finding emphasize the capability of capillary electrophoresis to determine sex and the species of birds simultaneously. Two samples originated from Falco tinnunculus produced larger CHD-Z amplicons (526 bp) than Lee et al. (2010) previously reported (522 bp). This suggests that length variability of $\mathrm{CHD}-Z$ region could be present within species and should be examined using a larger sample of the same species. Furthermore, Lee et al. (2010) analyzed only one male Falco tinnunculus bird. Finally, only one male animal in the study of Lee et al. (2010) and one female in our study are not enough for assessment of CHD-Z amplicon length variability.

Within certain species analyzed in this study (Buteo buteo, Falco tinnunculus, Cygnus cygnus) there was a difference in CHD-Z amplicons size. As suggested by Lee et al. (2010) intraspecies variations may be the cause of differences in CHD-Z gene segment size. Therefore, it is necessary to examine a larger number of individuals of a certain species. Along with a larger number of samples, both male and female individuals should be examined, because sometimes CHD-W fragment is an even better marker for species determination. This is supported by our results of analyzed Amazona species that revealed CHD-Z amplicons of the same size in more than one species, but in all cases length of CHD-W amplicon size was different (Amazona aestiva and Amazona ochrocephala; Amazona finschi, Amazona albiguens and Amazona albifrons in Table 1).

In species Ara chloroptera and A. macao (Psittaciformes) the size of CHD-Z fragment had the same length (521 bp) and therefore cannot be used to distinguish species when only males are analyzed. The absence of species-specific length of the CHD-sequences may be due to the existence of more than 300 species in ordo Psittaciformes, meaning that it is almost impossible that each species has unique size of CHD-Z fragment. 
Such a problem does not apply to females due to the huge variability in the CHD-W fragment, so the species can be easily determined (sample No 38 and 39 in Table 1).

We believe that for forensic application, a probabilistic approach is the only possible solution for strengthening species identification using capillary electrophoresis. The probability of fragment drop-outs as well as the inclusion of fragment length frequencies, in species where more than one fragment length is observed have to be included. On the other hand, discrimination between species whose fragments differentiate by only one base pair is also questionable since the same PCR product can vary that much even between two consecutive runs [25].

There is a difference in size between intronic sequences within CHD-Z and CHD-W fragments and this size difference allows determination of sex in many bird species by molecular techniques capable to separate fragments that differ in a very small number of base pairs (even only one in some cases). When it comes to sex determination in sampled birds using a dye-labelled CHD1F/CHD1R primer set, capillary electrophoresis proved to be an accurate, fast, and reliable method. Our results confirmed that the specified method enabled accurate sex determination in all tested species, although end point PCR approach was also highly successful, as shown here, but also in previous studies [7,9,10,26,27].

The study by Griffits et al. (1998) [28] has shown that the two PCR primers anneal to conserved exonic regions but then amplify across an intron in both CHD-W and CHD-Z. As these introns are noncoding and consequently less conserved, their lengths usually differ between the genes of different species which is followed by the variation of of PCR product lengths between species.

In all cases processed in this study, the sex obtained on an agarose gel was confirmed by capillary electrophoresis. On agarose gel, samples from heterozygous female individuals showed two bands while one band was obtained from homozygous males. The exceptions were Strigiformes samples where only one band was observed, regardless of sex. Difference in CHD-Z and CHD-W amplicon size in phylogenetically close species is expected to be 30-50 bp, but may be in range from 10 to $80 \mathrm{bp}$ [7]. In those species, it is difficult to distinguish female from male birds on agarose gel because females can often be misinterpreted as male birds [7,21]. Our results confirm that capillary electrophoresis overcomes those shortages in sex differentiation with simultaneous determination of bird species.

\section{CONCLUSION}

Capillary electrophoresis is of great importance for the identification of both sex and species of birds and can be used in ecology, genetics, biodiversity and veterinary forensics cases. Determination of sex and species of birds could be an important forensic tool in preventing wildlife smuggling. 


\section{Acknowledgement}

The study was supported by the Ministry of Education, Science and Technological Development of the Republic of Serbia (Contract no. 451-03-9/2021-14/200143, for the project III46002 led by Zoran Stanimirovic).

\section{Author's contribution}

DD conceived the study, design and participate in writing of the manuscript. MV participate in study design and writing of the manuscript. UG and IS carried the experiment and participated in manuscript writing. VN participated in manuscript writing and its critical revising. JS made substantial contribution to interpretation od data and writing the manuscript. ZS coordinated experiment and participated in critical revising of the manuscript. All authors read and approved the final manuscript.

\section{Declaration of conflicting interests}

The author(s) declared no potential conflicts of interest with respect to the research, authorship, and/or publication of this article.

\section{REFERENCES}

1. Alves RRN, Lima JRDF, Araujo HFP: The live bird trade in Brazil and its conservation implications: an overview. Bird Conserv Int 2013, 23(1):53-65.

2. Jan C, Fumagalli L: Polymorphic DNA microsatellite markers for forensic individual identification and parentage analyses of seven threatened species of parrots (family Psittacidae). PeerJ 2016, 4: e2416.

3. TRAFFIC: An overview of seizures of CITES-listed wildlife in the European Union, 2020.

4. Channing M: Transnational Crime and the Developing World. Global Financial Integrity 2017.

5. Pravilnik o proglašenju i zaštiti strogo zaštićenih i zaštićenih divljih vrsta biljaka, životinja i gliiva ("Sl. glasnik RS", br. 5/2010 i 47/2011)

6. Weston MK, Memon MA: The illegal parrot trade in Latin America and its consequences to parrot nutrition, health and conservation. Bird Pop 2009, 9: 76-83.

7. Vucicevic M, Stevanov-Pavlovic M, Stevanovic J, Bosnjak J, Gajic B, Aleksic N, Stanimirovic Z: Sex Determination in 58 Bird Species and Evaluation of CHD Gene as a Universal Molecular Marker in Bird Sexing. Zoo Biol 2013, 32:269-276.

8. Bosnjak J, Stevanov-Pavlovic M, Vucicevic M, Stevanovic J, Simeunovic P, Resanovic R, Stanimirovic Z: Feasibility of noninvasive molecular method for sexing of parrots. Pak J Zool 2013, 45:715-720.

9. Stevanov-Pavlovic M, Vucicevic M, Bosnjak J, Stevanovic J, Dimitrijevic V, Resanovic R, Stanimirovic Z: Molecular sex determination of 20 bird species protected in the Republic of Serbia. Acta Vet-Beograd 2013, 63:45-51. 
10. Lee JC, Tsai LC, Hwa PY, Chan CL, Huang A, Chin SC, Wang LC, Lin JT, Linacre A, Hsieh HM: A novel strategy for avian species and gender identification using the CHD gene. Mol Cell Probes 2010, 24:27-31.

11. Davitkov D, Glavinic U, Nesic K, Davitkov D, Vucicevic M, Nesic V, Stanimirovic Z: Improved DNA-based identification of Cervidae species in forensic investigations. Acta Vet-Beograd 2017, 67(4):449-458.

12. Dalén L, Lagerholm VK, Nylander JA, Barton N, Bochenski ZM, Tomek T, Rudling D, Ericson PG, Irestedt M, Stewart JR: Identifying bird remains using ancient DNA barcoding. Genes 2017, 6:169.

13. Hebert PDN, Stoeckle MY, Zemlak TS, Francis CM: Identification of Birds through DNA Barcodes. PLoS BIOL 2004, 2 (10):e312.

14. Rudnick JA, Katzner TE, Bragin EA, DeWoody JA: Species identification of birds through genetic analysis of naturally shed feathers. Mol Ecol Notes 2007, 7(5):757-762.

15. Ushio M, Murata K, Sado T, Nishiumi I, Takeshita M, Iwasaki W, Miya M: Demonstration of the potential of environmental DNA as a tool for the detection of avian species. Sci Rep 2018, 14:8(1):1-10.

16. Manthey JD, Campillo LC, Burns KJ, Moyle RG: Comparison of target-capture and restriction-site associated DNA sequencing for phylogenomics: a test in cardinalid tanagers (Aves, Genus: Piranga). Syst Biol 2016, 1:65(4):640-50.

17. Perktaş U, Groth JG, Barrowclough GF: Phylogeography, species limits, phylogeny, and classification of the turacos (Aves: Musophagidae) based on mitochondrial and nuclear DNA sequences. Am Mus Novit 2020, 3949:1-61.

18. Farag M, Imam T, Dhama K: Identification of some domestic animal species (camel, buffalo and sheep) by PCR-RFLP analysis of the mitochondrial cytochrome b gene. Adv Anim Vet Sci 2015, 3(2):136-142.

19. Rahat MA, Haris M, Ullah Z, Ayaz SG, Nouman M, Rasool A, Israr M: Domestic animals' identification using PCR-RFLP analysis of cytochrome b gene. Adv life sci 2020, 7 (3): 113-116.

20. Klomtong P, Phasuk Y, Duanginda M: Animal species identification through high resolutionmelting real time PCR (HRM) of the mitochondrial 16S rRNA gene. Ann Anim Sci 2016, 16:415-424.

21. Çakmak E, Akın Pekşen Ç, Bilgin CC: Comparison of three different primer sets for sexing birds. J Vet Diagn Invest 2017, 29:59-63.

22. Morinha F, Cabral JA, Bastos E: Molecular sexing of birds: A comparative review of polymerase chain reaction (PCR)-based methods. Theriogenology 2012, 78:703-714.

23. Centeno-Cuadros A, Abbasi I, Nathan R: Sex determination in the wild: a field application of loop-mediated isothermal amplification successfully determines sex across three raptor species. Mol Ecol Resour 2017, 17:153-160.

24. Rahim A, Kumar S, Sharma D, Kokate LS, Das AK, Singh JA, Kataria MC. Species and gender identification in diversified poultry species by PCR analysis of CHD gene. Indian Journal of Poultry Science 2012, 47(3):281-6.

25. Gill P, Gusmão L, Haned H, Mayr WR, Morling N, Parson W, Prieto L, Prinz M, Schneider $\mathrm{H}$, Schneider PM, Weir BS: DNA commission of the International Society of Forensic Genetics: Recommendations on the evaluation of STR typing results that may include dropout and/or drop-in using probabilistic methods. Forensic Sci Int Genet 2012, 6(6):679-88. 
26. De Andrade Silva KVK, Lôbo-Hajdu G, Alves MAS: Sex determination in Turdus amaurochalinus (Passeriformes: Muscicapidae): morphometrical analysis supported by CHD gene. Rev Biol Trop 2011, 59(2):789-794.

27. Khan S, Ijaz J, Hayat M, Zahra T, Raza M, Abbas K: Sex determination by CHD (Chromo helicase DNA binding) gene in local rock pigeons (Columba livia) from Lahore, Pakistan. J Entomol Zool 2019, 7:664-666.

28. Griffiths R, Double MC, Orr K, Dawson RJG: A DNA test to sex most birds. Mol Ecol 1998, 7:1071-1075.

\section{MOGUĆNOST UPOTREBE INTERSPECIJSKE I INTRASPECIJSKE VARIJABILNOSTI CHD1 GENA PTICA U FORENZICI}

Dajana DAVITKOV, Milos VUCICEVIC, Uros GLAVINIC, Ivan SKADRIC, Vladimir NESIC, Jevrosima STEVANOVIC, Zoran STANIMIROVIC

Ilegalna trgovina i krijumčarenje divljim vrstama danas predstavlja jednu od najvećih pretnji koje ugrožavaju populacije velikog broja ptica. Najčešće vrste kojima se ilegalno trguje su papagaji, ptice pevačice, grabljivice i sove. Sve ove vrste ptica su zaštićene nacionalnim ili međunarodnim zakonskim regulativama. U cilju prevencije $i$ smanjenja ilegalne trgovine, molekularne metode su postale bitno forenzičko oruđe u identifikaciji vrste i pola zaštićenih vrsta ptica. U ovom istraživanju ispitano je ukupno 65 uzoraka ptica (ukupno 43 vrste), a u cilju umnožavanja dela CHD1 gena korišćen je CHD1R/CHD1F par prajmera. Za 36 vrsta ovo je prvi put da je dužina CHD1 gena određivana u cilju identifikacije vrste. Dobijeni produkti su vizuelizovani koristeći kapilarnu elektroforezu i omogućili su simultano određivanje pola i vrste. $\mathrm{Na}$ osnovu analize amplikona (dva kod ženke, jedan kod mužjaka), pol je uspešno identifikovan kod svih vrsta, čak i kod onih kod kojih gel elektroforeza nije bila uspešna.Vrsta je uspešno određena kod većine ptica na osnovu veličine CHD1 amplikona specifične za vrstu. Metoda korišćena u ovoj studiji je od velikog značaja u veterinarskoj forenzici i prevenciji ilegalne trgovine životinjama. Ipak, dalji rad na ovoj metodi je neophodan da bi se potvrdila efikasnost metode na svim vrstama ptica. 